\title{
BARRIERS RESPONSIBLE TO FEMALES' LOW LITERACY AT THE PRIMARY LEVEL IN BALOCHISTAN PROVINCE OF PAKISTAN: SOCIAL AND ECONOMIC BARRIERS
}

\author{
Falsafa Zareef Khan ${ }^{1}$, Muhammad Kamran ${ }^{2 *}$, Abdul Ahad Roshan Saeed ${ }^{3}$, Waqar Un Nisa Faizi ${ }^{4}$ \\ ${ }^{1}$ Research Scholar in Education, Islamabad, Pakistan; ${ }^{2 *}$ Assistant Professor in Education, University of Loralai, \\ Balochistan, Pakistan; ${ }^{3}$ Lecturer in Education, Mir Chakar Khan Rind University Sibi, Balochistan, Pakistan; ${ }^{4}$ Assistant \\ Professor in Education, Islamia College University Peshawar, Pakistan. \\ Email: ${ }^{1}$ khan.khan12380@yahoo.com, ${ }^{2 *}$ kamrankundi86@gmail.com, ${ }^{3}$ iamroshansaeed@gmail.com, ${ }^{4}$ faizi@icp.edu.pk
} Article History: Received on $25^{\text {th }}$ April 2021, Revised on $2^{\text {nd }}$ May 2021, Published on $5^{\text {th }}$ May 2021

\begin{abstract}
Purpose of the study: This study finds the barriers responsible for females' low literacy in the Balochistan province of Pakistan at the primary school level.

Methodology: Qualitative research design was applied to this study. Data were collected through the interview tool and were analyzed through a thematic analysis procedure. Results were given in the form of major themes and sub-themes.

Main Findings: This study gave 4 major results, which were in the form of four major themes, i.e., lack of basic facilities, lack of qualified teachers, lack of enrolment, and financial constraints. The major themes were categorized into several sub-themes.
\end{abstract}

Applications of this study: This study is beneficial and applicable in Pakistani society. It attracts the attention of the layman and government to focus on female education to make the females literate at the best level.

Novelty/Originality of this study: The new aspect of this study was to show the barriers responsible for females' low literacy. It is aware of the readers that lack of basic facilities, lack of qualified teachers, lack of enrolment, and financial constraints are the barriers to females' low literacy. It also advances the existing knowledge and bridges the gap between past and existing knowledge.

Keywords: Barriers, Females' Low Literacy, Primary Level, Society, Economy.

\section{INTRODUCTION}

Balochistan is the largest province of Pakistan by area (347190 sq km), making $43.6 \%$ of Pakistan's total by area, but it is the least populated province in Pakistan. Its population is less than all the provinces of Pakistan (LATEST NEWS, 2021). According to EFA (Education for All) goals, education is the key to nations' socio-economic development (Durrani, Halai, Kadiwal, Rajput, Novelli \& Sayed, 2017; Hussain, Salfi, \& Mahmood, 2011; Kamran, Abasimi, \& Congman, 2015). Latif (2009) explained that the definition of the literate is the one who can read the newspaper or can write a simple letter in the native language or any other language, and this definition reflects the definition of United Nations about a literate person. Low literacy produces many problems such as political unawareness, poverty, terrorism, and crimes (Memon, Joubish \& Khurram, 2010; Durrani \& Halai, 2018). The Pakistan Integrated Household Survey (2001) stated numerous causes of low enrolment and low literacy in Balochistan (Toor \& Parveen, 2004).

The recent Human Development Report (2019-20) issued that UNDP (United Nations Development Program) stated in its HDI (Human Development Index) that Pakistan is far away on the list of 189 countries who developed well, especially in education and out of 189 countries Pakistan is ranked at 152 which means that 151 countries are advanced of Pakistan in the development (Pakistan Economic Survey, 2019-20). It is also regrettable to say that Pakistan did not get any improvement in some of the essential educational factors like literacy rate, enrolment ratio, and expenditure on education which means that Pakistan is also far back on the above-mentioned educational factors among the neighboring regional countries (Pakistan Economic Survey, 2019-20). It is further stated that except Afghanistan, Pakistan is far behind Iran, Sri Lanka, Maldives, India, Bhutan, Bangladesh, and Nepal mentioned by Human Development Report2019 (Pakistan Economic Survey, 2019-20).

In Pakistan, various studies (e.g., Ara \& Aziz, 2013; Hussain, Salfi \& Mahmood, 2011; Qaisar, Butt, \& Shiraz, 2020) have been conducted on the barriers, problems, and challenges faced to females during their education (Durrani \& Dunne, 2010) in other provinces of Pakistan. The case of Balochistan is limited, different and, unique from other provinces because only limited studies have been conducted about the province of Balochistan regarding barriers to females' education.

\section{Significance of the Study}

Better literacy can be ensured only by creating public awareness and providing the people with modern education. This study offers practical thoughts on removing barriers to females' literacy in Balochistan. It also suggests recommendations to the difficulties faced by researchers, policymakers, and government administrators in the cause of primary education in the province. This study will help the relevant authorities make the right decision to increase 
females' enrolments in schools in the least developed province of the country. Since females' education makes a major theme, this study will help the government fix the dismally low literacy rate among females. This study will also provide solid reasons for the people to act against social and cultural barriers to the cause of dejectedly low literacy. The study offers a reference to other researchers working on females' education.

\section{Statement of the Problem}

Various studies (e.g., Ara \& Aziz, 2013; Hussain, Salfi \& Mahmood, 2011; Qaisar, Butt, \& Shiraz, 2020) have been conducted about barriers to females' low literacy at the primary school level in Pakistan, but for Balochistan, there is very scarce research regarding the under-research phenomenon. Therefore, this study aims to add to the existing literature by examining the barriers to females' low literacy from the perspective of Balochistan. This research is planned to delimit the study at the Balochistan level only.

\section{Research Question}

What are the barriers responsible for females' low literacy in Balochistan at the primary school level?

\section{LITERATURE REVIEW}

Many students come into the teaching profession for a life (Noor, Akram, \& Kamran, 2021). Also, girls' education in Pakistan is a serious issue. Various research reports and studies have indicated the girls' education. The underdeveloped and developing countries still have not fully achieved girls' education in complete sense. Numerous UNESCO reports have also dug deep into this matter and conducted various research reports on this severe issue (Shah \& Shah, 2012). In the following lines, this study has underlined several research studies conducted in the past that have been proven for the factors responsible for the barriers to females' education and females' low literacy rate in Pakistan (Khan, Kamran \& Andaleeb, 2017).

$\underline{\text { Jamal (2016) }}$ conducted his study on girls' education in Pakistan and stated that numerous barriers reduce girls' education in Pakistan. Further, Pashtun areas are the most affected areas for girls' low education in Pakistan because the lowest enrolment of the girls is found in the Pashtun areas of the country. In this study, the Pashtun men's perception regarding girls' education was dug deep through the in-depth and detailed interviews using Delphi Research Design. The results that came from the interviews revealed that some of the barriers to girl's education are poverty, Pashtunwali (code of Pashtun society), lack of accessibility, lack of resources, shortage of female teachers, curriculum, political apathy, and corruption. These barriers prevent and stop the females from education, leading to low literacy and low enrolment of girls in education (Jamal, 2014).

Conducting mixed-method research regarding girls' enrollment at the secondary level in the province of Sindh Ara and Aziz (2013) also believed that numerous barriers prevent and halt the females from education in Pakistan. Ara and Aziz (2013) sought the parents' perceptions regarding females' education in Pakistan (Sindh). The main barriers and fences shown in this study were poverty, insecurity, and girls' attitudes from the community and parents. Through these barriers and fences, females' literacy might go down in Pakistan.

Likewise, Shah and Shah (2012) also conducted a study on girls' education in rural areas of Pakistan at the primary school level to find the factors that pause and break the girls' education in the region. The respondents (i.e., parents, teachers, and students) were interviewed regarding girls' education from which profound and deep results were obtained, e.g., lack of educational facilities and poverty hit the education leading to girls' low enrolment and low literacy in Pakistan. They further stated that rural populations still lack educational facilities, and high poverty exists, which has declined the females' educational development in Pakistan. According to the said study, the decreasing budget for education and misutilization of the partial resources has already worsened girls' education in Pakistan. It leads to the deteriorating future of girls' education in Pakistan.

The primary purpose of Noureen and Awan (2011) was to focus on the importance of women's education in Pakistan and to find those barriers and obstacles that prevent the girls from education. They revealed barriers and impediments that girls face while getting an education. The most significant barriers and railings to girls' education were poverty, social norms like dowry, and early marriages of the girls.

Khalid and Mukhtar (2002) were also aware of numerous hurdles and blockades that can deteriorate and decline the country's literacy rate. The obstructions and barriers responsible for females' low literacy were poverty and the lower status of the females given to them in rough societies due to the caste system. The concern regarding female security was also shown up as a barrier according to Khalid and Mukhtar (2002). Besides, lack of basic infrastructure, lack of basic educational facilities, and absence/lack of female teaching staff in the schools are myriad barriers that depreciate the country's literacy rate.

\section{Conceptual Framework of the Study}

A conceptual framework (figure 1) was created by several themes generated from the literature review. This framework elaborates on the barriers to females' literacy at the primary school level in Balochistan. It revolves around a research question of the study which seeks and explains that education is expensive, schools are a far distance from home, 
teachers' strict attitudes, lack of parents' awareness, old and difficult curriculum are the barriers to females' literacy (슬 \& Aziz, 2013; Jamal, 2016; Khalid \& Mukhtar, 2002; Noureen \& Awan, 2011; Shah and Shah, 2012). The factors mentioned above are the barriers that prevent and halt the fathers from sending their daughters to schools. The other essential issues that are reflected by the conceptual framework is lack of basic educational facilities, high poverty, low budget for education, parents' low economic status (Pirzado, 2006; Rao \& Gupta, 2006), due to which the girls can't go to schools because fathers can't send their daughters to schools due to their daily house chores. The current study has used this conceptual framework comprising of barriers to females' literacy, as shown in Figure I below.

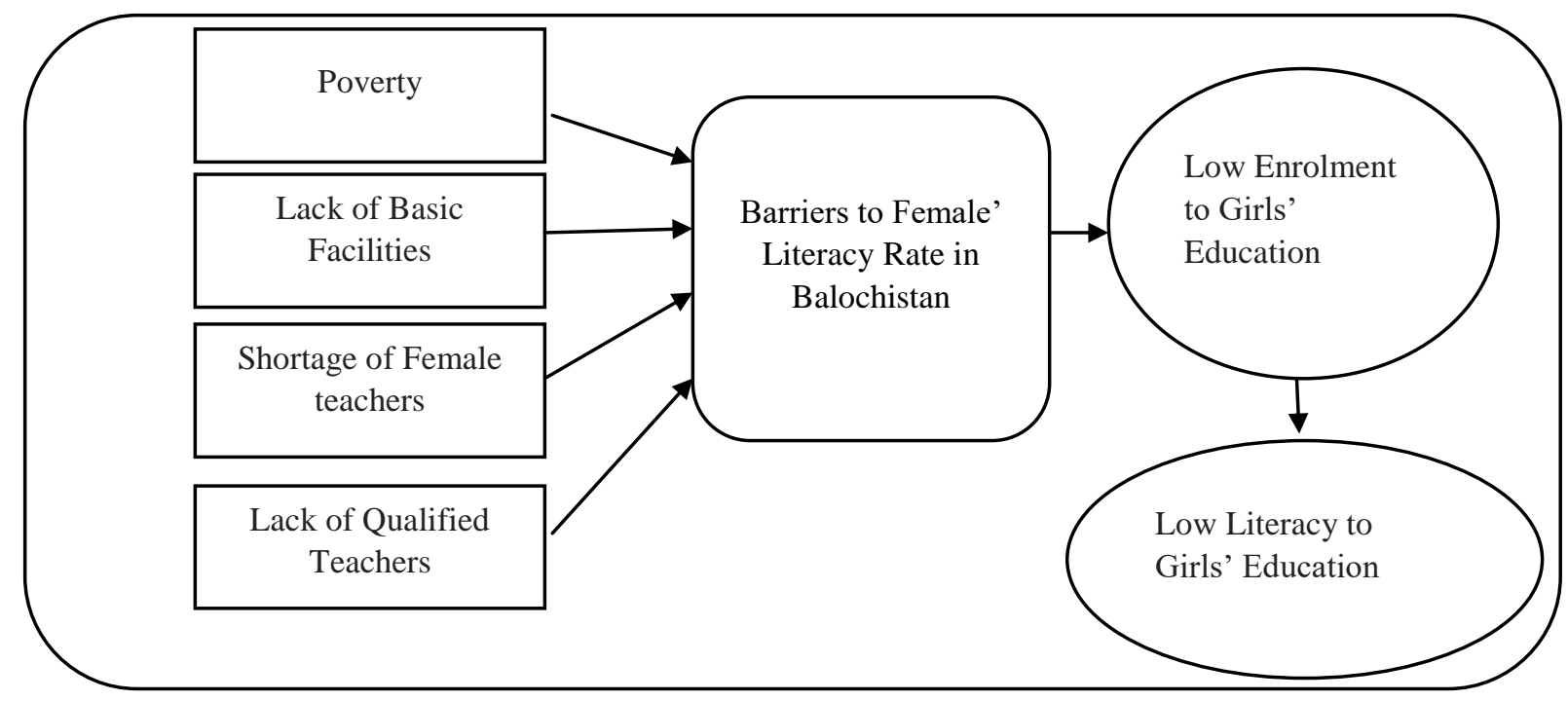

Figure 1: Conceptual framework of the study based on aspects of barriers to females' literacy at the primary school level

\section{METHODOLOGY}

This study utilizes qualitative design through a case-study approach to achieve the intended research question (Bukhari, Said, \& Nor, 2020; Gul \& Khilji, 2021). Considering the opinion of Creswell (2014), qualitative research is comprehensive and depth exploration using words stated by participants in a naturally occurring scenario. Such qualitative research design has already been used by numerous researchers (e.g., Kamran, Shah \& Rao, 2017), which substantiated the logic for the current study. The case-study approach leads to the extraction of detailed and thick descriptions of the variables under the study via reporting of natural verbatim by the respondents, which may include interview transcriptions and memos (Creswell, 2014). Case-study is also the detailed description and analysis of a single or multiple cases/events. Several data collection strategies can be used in its original and real natural settings (Baxter \& Jack, 2008; Creswell, 2014) in case studies.

\section{Study Area, Sample Size, and Data Collection Tool}

This study was delimited to government and private schools of Quetta city in Balochistan. The population of the study consisted of all primary schools. In contrast, the area of Quetta, which the researcher selected, was tribal and highly conservative, especially in girls' education. Through a convenient sampling technique, six primary girls' schools (15 teachers) were chosen from the area where girls have poor or no formal learning access. All 15 respondents were interviewed. It is worth mentioning that schools were located in backward areas of Quetta city. The researcher visited them and spoke to the respondents. The researcher obtained permission from head-teachers of those schools through a consent form before interviews. After the approval of the consent form, the researcher set two weeks for face-to-face interviews. The researcher made phone calls to respondents to reminding about the interviews. Teachers, particularly females, were more passionate than male teachers regarding the interviews. The interview questions were semistructured and were meant to collect demographic information of interviewees and their opinion on the barriers to girls' literacy in Balochistan.

Interviews covered general hurdles to girls' education. Interview questions were put to every respondent, developed in Urdu, the country's national language. The interviews were recorded before being translated into English and transcribed. For the validation of the data, a pilot study was conducted in the field among 5 respondents. The researchers assured interviewees before questioning them that their views and information be used for research purposes, so only pseudonyms were used. The researcher visited the interviewees one by one at their convenience and electronically recorded their opinion of their own free will for data compilation. Field notes were also taken. On average, each interview lasted 45 minutes. In some instances, interviews were done over the telephone for the comfort of the respondents. The demographic information of all of the respondents is shown below in table 1 . 
Table 1: Demographic Characteristics of the Participants

\begin{tabular}{llllll}
\hline S.No & Pseudonyms of Parents & Gender & Age (Years) & Qualification & Profession \\
\hline 1 & AK1 & Male & 36 & MS & Teaching \\
\hline 2 & Res2 & Male & 40 & BA & Teaching \\
\hline 3 & A1 & Male & 38 & MA & Teaching \\
\hline 4 & Jan1 & Male & 28 & BA & Teaching \\
\hline 5 & Khu1 & Male & 30 & MSc & Teaching \\
\hline 6 & Nas1 & Male & 36 & Bed & Teaching \\
\hline 7 & Zee1 & Male & 42 & Med & Teaching \\
\hline 8 & A1 & Female & 25 & MSc & Teaching \\
\hline 9 & W2 & Female & 26 & Bed & Teaching \\
\hline 10 & R3 & Female & 23 & Med & Teaching \\
\hline 11 & F1 & Female & 24 & MS & Teaching \\
\hline 12 & R2 & Female & 28 & MS & Teaching \\
\hline 13 & SK1 & Female & 32 & MA & Teaching \\
\hline 14 & R1 & Female & 02 & BSc & Teaching \\
\hline 15 & S1 & Female & 30 & Undergraduate & Teaching \\
\hline
\end{tabular}

\section{Data Analysis}

Two interview guides were developed for the interviewees; one guide had seven questions about the participants' demographic information. Respondents actively participated in the interviews and responded well to questions, and were enthusiastic and cooperative during interviews. During the analysis stage, the qualitative data passed through several steps, e.g., data transcription, categorizing the whole data into main themes, and then generating codes (Manen, 1984). To carry out the data analysis properly, the researchers identified the meaning of each theme. They developed the themes based on categories generated. Finally, codes were given (Graneheim \& Lundman, 2004) and were organized into connective themes according to the study's research question mentioned above. Such data analysis has already been used and substantiated by other researchers (e.g., Kamran \& Shahbaz, 2019; Akram, Kamran \& Ahmad, 2020).

\section{Ethical Considerations}

During the study, the current researchers considered all ethical matters. The informed consent was given to participants to ensure confidentiality. Before the interview sessions, they were briefed about the purpose of the research, while verbal consent was taken from participants to provide information. Three people, primarily females, showed reluctance, and therefore, they were excluded from the interview sessions.

\section{RESULTS and DISCUSSION}

\section{Research Question: What are the barriers to females' literacy in Balochistan at the primary school level?}

The above research question had 4 major themes, i.e., lack of basic facilities, lack of qualified teachers, lack of enrolment, and financial constraints. The major themes were categorized into several sub-themes, as mentioned in table 2. below.

Table 2: Major Themes, Sub-themes, and Frequencies

\begin{tabular}{|c|c|c|c|c|c|}
\hline $\begin{array}{l}\text { S. } \\
\text { No }\end{array}$ & Major Themes & Sub-themes & Frequency & $\begin{array}{l}\text { Total } \\
\text { Frequency }\end{array}$ & $\begin{array}{l}\text { Research } \\
\text { Question }\end{array}$ \\
\hline \multirow{3}{*}{1} & \multirow{3}{*}{$\begin{array}{l}\text { Lack of } \\
\text { Facilities }\end{array}$} & Infrastructure Deficiency & 09 & 13 & \multirow{10}{*}{$\begin{array}{l}\text { What are the } \\
\text { barriers to } \\
\text { females' literacy } \\
\text { in Balochistan at } \\
\text { the primary } \\
\text { school level? }\end{array}$} \\
\hline & & Technology Deficiency & 03 & & \\
\hline & & $\begin{array}{l}\text { Uniform and Stationery } \\
\text { Deficiency }\end{array}$ & 01 & & \\
\hline \multirow[t]{3}{*}{2} & \multirow[t]{3}{*}{$\begin{array}{l}\text { Lack of Qualified } \\
\text { Teachers }\end{array}$} & $\begin{array}{l}\text { Qualified } \\
\text { Deficiency }\end{array}$ & 03 & \multirow[t]{3}{*}{05} & \\
\hline & & $\begin{array}{l}\text { Teachers } \\
\text { Deficiency }\end{array}$ & 01 & & \\
\hline & & Short of teaching staff & 01 & & \\
\hline \multirow[t]{2}{*}{3} & \multirow[t]{2}{*}{ Lack of Enrollment } & Increase enrolment rates & 02 & \multirow[t]{2}{*}{03} & \\
\hline & & $\begin{array}{l}\text { Low school enrolment } \\
\text { rates }\end{array}$ & 01 & & \\
\hline \multirow[t]{2}{*}{4} & \multirow[t]{2}{*}{ Financial Constraints } & $\begin{array}{ll}\text { People's } & \text { financial } \\
\text { constraints } & \\
\end{array}$ & 01 & \multirow[t]{2}{*}{09} & \\
\hline & & Agricultural sector & 02 & & \\
\hline
\end{tabular}




\begin{tabular}{ll} 
Low-income earners & 01 \\
\hline Large families to feed & 01 \\
\hline High poverty level & 01 \\
\hline Not enough money & 01 \\
\hline $\begin{array}{l}\text { Families work in } \\
\text { industries }\end{array}$ & 01 \\
\hline Girls stay indoors & 01
\end{tabular}

\section{Lack of Basic Facilities}

The first most repeated major theme which the respondents showed was the lack of basic facilities. Its total frequency was 13, which meant that it was revised 13 times by the respondents. It meant that out of four barriers, the top-rated barriers to females' low literacy in Balochistan was the lack of basic facilities. Through the unanimous opinion of the respondents, schools in Balochistan were poorly equipped. The participants came up with different answers when asked about missing facilities, e.g., a private primary school teacher stated that "Mostly chairs, tables, technology, wellqualified teachers (are missing from schools). There is a great need for better infrastructure. Lack of playgrounds, school uniform, stationary and highly qualified teachers are required who can influence the personality of a child in a better way (Participant R1)." Another Participant further emphasized, "The government's educational institutions mostly lack furniture, modern teaching tools and equipment, and playgrounds. If such facilities are missing, just tell me how the parents can send their children to schools. There is a need for equipping schools to increase enrolment rates (Participant R2)."

The more the schools have basic facilities, the more chances of enrolling in schools. The participants regretted that schools in Balochistan have lack basic facilities like lack of classrooms, furniture, toilets, and water. In their opinion, the more the schools are equipped, the more will be chances of enrolling in schools. For example, one participant emphasized that "the government should increase schools' infrastructure. The schools' network must be extended through far-fledged areas of Balochistan and need to be equipped with basic facilities (participant SK1)".

Regarding the lack of basic educational facilities, these findings of the current study were supported by Shah and Shah (2012), who found the factors that affect girls' education. Shah and Shah (2012) further revealed that lack of educational facilities could lead to low enrolment and low literacy, especially for girls in Pakistan. They further stated that basic educational facilities are worse in rural areas compared to urban due to which it has declined the educational development in rural areas of Pakistan. Further, the misutilization of the partial resources has already degraded the situation in Pakistan. It leads to the worsen future of education, especially the girls' education in Pakistan. The current study findings also fully support this indication that the students cannot fulfill their educational dreams due to a lack of educational facilities. If any institution lacks the educational facilities and cannot provide the latest teaching material, then the quality of education will not be possible in that atmosphere (Khalid \& Mukhtar, 2002; Shah \& Shah, 2012).

Regarding poor access and lack of transport facilities, the findings of this study are supported by Jamal (2016). He stated that girls don't feel they go to school because of security and safety reasons. The parents also feel reluctant to send their daughter to school. Hence, it is concluded that these barriers and cordons lead to females' low literacy in Balochistan.

\section{Lack of Qualified Teachers}

The total frequency of this theme was 05 , which meant that it was revised 05 times by the respondents. Participant, a private primary school teacher, stated that " highly qualified teachers are required who can influence the personality of a child in a better way (Participant F1)." The next Participant, the father of a primary school child, said, "first, most schools are short of teaching staff members, and second, the teachers employed by them are neither qualified nor trained enough. Such teachers resort to old tutoring techniques (Participant A1)." The more the schools have skilled teaching staff members, the more chances of enrolling in schools.

The participants were worried about the teaching staff, as is mentioned in their interviews. In their opinion, the more the schools are equipped and have skilled teaching staff members, the more will be chances of enrolling in schools. They further stated that reasons had been many to prevent the girls from education, such as social taboos, and tribal labels, etc. Also, the absence of enough schools, ghost schools, and lack of female teaching staff are the aspects that barricade the females from education in Balochistan. The current study supported the views of Khalid and Mukhtar (2002) because if there are no qualified teachers or if there is a lack of female teaching staff, then educational standards cannot be sustained. It will lead to the girls' low literacy in the country. Jamal (2016) also believed that a lack of qualified teachers, especially the shortage of female teaching staff, can badly affect the girl's literacy rate. In rural areas of Pakistan, it has been observed that male teachers teach to male students and female teachers teach to female students. According to this perception, if the female teaching staff is not available, the girls will feel reluctant to go to the schools where male teaching staff is teaching. This will also lead to the girls' low literacy in Pakistan, especially in Balochistan.

\section{Lack of Enrolment}

The total frequency of this theme was 03 , which meant that it was revised 03 times by the respondents. Regarding lack 
of enrolment in schools, this participant emphasized, "If such facilities are missing, just tell me how the parents can send their children to schools. There is a need for equipping schools to increase enrolment rates (participant A1)." The next participant revealed his viewpoint as "Boys of such families work in industries, the agricultural sector, and other professions, while girls stay indoors to do household chores. As a result, enrolments in schools are very low (Participant $A K 1)$."

Regarding the lack of enrolment in schools, the current study's findings agree with Ara and Aziz (2013), who conducted their study regarding girls' enrolment in education at the secondary level. Ara and Aziz (2013) have focused on girls' education by seeking the parents' perceptions and discussed the barriers responsible for females' low literacy in Sindh province. These barriers were poverty, insecurity, and girls' attitudes from the community and parents. Due to these barriers, girls' enrolment in schools becomes low.

Literacy might go down in Pakistan because of a lack of girls' enrollment in Balochistan schools. In such cases, the girls will be deprived of education, proving a significant loss to the nations. Besides, girls also faced deranged attitudes regarding their education from the community and parents, which can cause low enrollment in Balochistan schools. Regarding the lack of enrolments in schools, Shah and Shah (2012) supported the current study's findings. They revealed that lack of educational facilities and poverty could lead to low enrolment in schools, which can lead to low literacy, especially to girls' education in Pakistan (Durrani, 2008; Westbrook, Pryor, Orr, \& Durrani, 2013).

\section{Financial Constraints}

The total frequency of this theme was 09, which meant that it was revised 09 times by the respondents. Regarding financial constraints, a public school (teacher) said, "The people's financial constraints are a major reason for low school enrolment rates in our province of Balochistan. Most of our people are directly or indirectly associated with the agricultural sector. Since they're low-income earners and have large families to feed, therefore, cannot send children to schools. Therefore, formal learning is not possible (Participant S1)'”. Most parents also agreed that financial confines undoubtedly play a vital role in the child's educational disability. The participants further revealed that though parents want to educate their daughters, they could not send their daughters to school just because of high tuition fees.

The next participant, a father with low income, considered poverty the foremost hurdle to literacy in Balochistan. He stated that we do not have enough finances to educate our daughters, so education is just a dream for needy children. "High poverty contributes to low literacy rate in Balochistan. Most of our people, especially those living in rural areas, do not have enough money to pay for the necessities of life, and therefore, sending children to schools is out of the question for them. Boys of such families work in industries, the agricultural sector, and other professions, while girls stay indoors to do household chores. As a result, enrolments in schools are very low (Participant AK1)".

Some participants, including both parents and teachers, complained about the high tuition fee. They said many in the province of Balochistan had a keen desire to send their daughters to school but struggled to do so to earn a meagre income. "Education should be given to the children free of charge for at least up to the eighth grade (Participant R3)". It was emphasized that the government should increase the education sector's budget to upgrade schools. Poverty has been mentioned as the primary cause of the low literacy of girls' education in Balochistan.

The findings of the current study agree with Ara and Aziz (2013), who expressed that poverty is considered a significant barrier for girls' enrolment in schools. Other past studies also show this barrier (e.g., Shah \& Shah, 2012), so it can be justified that poverty is the reason due to which the parents can't send their daughters to schools but rather keep them in the home for daily chores or make them able to help the parents in their daily earnings. High poverty is worse in rural areas, which has declined the educational development in Pakistan. According to the said studies (e.g., Ara \& Aziz, 2013; Shah \& Shah, 2012), the decreasing budget to education and misutilization of the partial resources has already worsened girls' education in Pakistan. Poverty is a significant concern (Khalid \& Mukhtar, 2002) to the girl's education in Pakistan because due to poverty, the students cannot fulfill their educational dreams.

Regarding poverty, the current study finding was also supported by Noureen and Awan (2011). They focused on women's education in Pakistan and found poverty as a barrier preventing girls from education. Jamal (2016) also stated poverty is the barrier due to which parents feel reluctance to send their daughters to schools.

\section{CONCLUSION}

This study was conducted on the barriers responsible to females' low literacy in the least developed province of Pakistan, i.e., Balochistan. The study's findings provided a broader concept regarding the barriers to females' literacy in Balochistan at the primary school level. The study found that most participants wanted an early end to the barriers regarding girls' education. The study answered the research question by finding the barriers responsible for females' low literacy, i.e., lack of basic facilities, lack of qualified teachers, lack of enrolment, and high financial constraints. The findings verified the results of the previous studies. This research has established the fact that giving education to girls is still unthinkable in many parts of the Balochistan province due to conservative norms, low household wealth, and parents' unawareness. The current study also concluded that the people with low or no literacy levels have fewer livelihood opportunities and are trapped in the vicious circle of poverty. This research concluded that all these barriers are socio-economic. 


\section{STUDY LIMITATIONS and SUGGESTIONS}

Though exploring the quality of education was necessitated, the researcher has limited the study to school teachers only due to the shortage of time and financial conditions. It covered only six primary schools of Quetta city, three of boys and girls each. The researcher struggled to continue with the study. Thus, there is a possibility of the study's findings showing slight variation. Further, the sample in this study was too limited; therefore, this study limits the generalizability of the study to the whole population of the Balochistan province. Besides, interviews were used as the data collection tool; future researchers should triangulate this type of study using questionnaires and observation tools, and interviews. It is also suggested that future researchers should use qualitative and quantitative research designs both to make the results generalizable. Since this study was only limited to Balochistan province, future researchers should extend such type of study to the other provinces of Pakistan to make the results more consistent and make the possibility of generalization.

\section{RECOMMENDATIONS}

After explaining the barriers and challenges of Balochistan's educational sector, especially the barriers to females' literacy, the current researchers recommend some corrective measures:

1. Females' education is essential for public awareness. The government should initiate a door-to-door campaign to educate the people about the benefits of sending daughters to schools. Compulsory education should be free.

2. The schools should be modernized through the provision of basic facilities and training of teachers. There is a need to hire qualified and skilled teachers in sufficient numbers and build the capacity of the already hired teachers through professional training programs.

3. There is a need for large-scale movement to counter feudal and tribal opposition to education, especially girls, for higher enrolment rates.

4. There should be better budgetary allocations for education in Balochistan, with the government using most of them in remote, unprivileged areas, especially at the primary school level, under a particular scheme.

5. The government is to be the vital authority in this regard. We need substantial efforts from the government on a colossal scale. Government should incentivize education besides providing schools with facilities and provide free education. They should give proper attention to economically backward and undeveloped areas and establish separate schools for girls.

\section{AUTHORS' CONTRIBUTION}

Falsafa Zareef Khan initiated the research work and wrote the introduction and literature review. She also collected the data for this research. Muhammad Kamran conducted the methodology of the study and draw the major themes and subthemes from the interviews of the participants. Abdul Ahad Roshan Saeed refined the literature review and methodology of the study. Waqar Un Nisa Faizi drew the conceptual framework. She also analyzed the data and drew the conclusion, discussion, and recommendations.

\section{REFERENCES}

1. Akram, H., Kamran, M., \& Ahmad, N. (2020). An Examination of the Encountered Challenges of Pakistani International Students in China: A Case Study of First-Year Students. Pakistan Journal of Social Sciences (PJSS), 40(4), 1567-1576.

2. Ara, A., \& Aziz, S. A. (2013). Impact of socio-economic status on the enrollment of girls students in public sector schools of district west Karachi. Educational Research International, 1(2), 32-38.

3. Baxter, P., \& Jack, S. (2008). Qualitative case study methodology: Study design and implementation for novice researchers. The qualitative report, 13(4), 544-559.

4. Bukhari, S. K. U. S., Said, H., \& Nor, F. M. (2020). Conceptual understanding of sustainability among academic administrators of Pakistan public universities. The Qualitative Report, 25(1), 28-59. https://doi.org/10.46743/2160-3715/2020.3235

5. Creswell, J. W. (2014). A concise introduction to mixed methods research. SAGE publications.

6. Durrani, N. (2008). Schooling the 'other': The representation of gender and national identities in Pakistani curriculum texts. Compare, 38(5), 595-610. https://doi.org/10.1080/03057920802351374

7. Durrani, N., \& Dunne, M. (2010). Curriculum and national identity: Exploring the links between religion and nation in Pakistan. Journal of Curriculum Studies, 42(2), 215-240. https://doi.org/10.1080/002 20270903312208

8. Durrani, N., Halai, A., Kadiwal, L., Rajput, S. K., Novelli, M., \& Sayed, Y. (2017). Education and social cohesion in Pakistan. Project Report. UNICEF.

9. Durrani, N., \& Halai, A. (2018). Dynamics of gender justice, conflict and social cohesion: Analysing educational reforms in Pakistan. International Journal of Educational Development,61, 27-39. https://doi.org/10.1016/j.ijedudev.2017.11.010 
10. Graneheim, U. H., \& Lundman, B. (2004). Qualitative content analysis in nursing research: concepts, procedures and measures to achieve trustworthiness. Nurse education today, 24(2), 105-112. https://doi.org/10.1016/j.nedt.2003.10.001

11. Gul, R., \& Khilji, G. (2021). Exploring the need for a responsive school curriculum to cope with the Covid-19 pandemic in Pakistan. Prospects, 1-20. https://doi.org/10.1007/s11125-020-09540-8

12. Hussain, A., Salfi, N., \& Mahmood, T. (2011). Causes of students' dropout at primary level in Pakistan: An empirical study. International journal of humanities and social science, 1(12), 143-151.

13. Jamal, A. (2014). Men's perception of women's role and girls' education among Pashtun tribes of Pakistan: A qualitative Delphi study. Cultural and Pedagogical Inquiry, 6(2). https://doi.org/10.18733/C3RC7B

14. Jamal, A. (2016). Why he Won't send his daughter to school-Barriers to girls' education in Northwest Pakistan: A qualitative Delphi study of Pashtun men. SAGE Open, 6(3), 2158244016663798. https://doi.org/10.1177/2158244016663798

15. Kamran, M., \& Shahbaz, M. (2019). Pakistani Secondary School Teachers' Perspectives on Choice of Profession. International Research Journal of Arts \& Humanities (IRJAH), 47(47).

16. Kamran, M., Abasimi, E., \& Congman, R. (2015). Comparative Study of the Attitudes of Education and NonEducation Students towards the Teaching Profession in Gomal University, Pakistan. International Education \& Research Journal (IERJ) 1 (4), 52-56.

17. Kamran, M., Shah, S. A., \& Rao, C. (2017). Secondary science teachers'views about the placement of creativity in secondary classes: a qualitative study. European Journal of Education Studies 3 (8), 838-851

18. Khalid, H. S., \& Mukhtar, E. M. (2002). The future of girls' education in Pakistan: A study on policy measures and other factors determining girls' education. Islamabad: UNESCO.

19. Khan, F. Z., Kamran, M., \& Andaleeb, N. (2017). Exploring The Barriers To Female Literacy From Parents And Teachers' perspective: A Review Study Of Scattered Literature. European Journal of Alternative Education Studies 2 (2), 41-52.

20. LATEST NEWS. (2021, March 25). Government of Balochistan. http://balochistan.gov.pk/

21. Latif, A. (2009). A critical analysis of school enrollment and literacy rates of girls and women in Pakistan. Educational Studies, 45(5), 424-439. https://doi.org/10.1080/00131940903190477

22. Memon, G. R., Joubish, F. M., \& Khurram, A. M. (2010). Impact of parental socio-economic status on students' educational achievements at secondary schools of district Malir, Karachi. Middle-East Journal of Scientific Research, 6(6), 678-687.

23. Noor, N., Akram, H., \& Kamran, M. (2021). Preferred reasons in selecting teaching profession as a life career: a case study of pre-service teachers. Pakistan Journal of Educational Research, 4(1).

24. Noureen, G., \& Awan, R. (2011). Women's education in Pakistan: hidden fences on open frontiers. Asian Social Science, 7(2), 79-87. https://doi.org/10.5539/ass.v7n2p79

25. Pakistan Economic Survey 2019-20. (n.d.). Education. Retrieved March 31, 2021, from http://www.fina nce.gov.pk/survey/chapter_20/10_Education.pdf

26. Pirzado, P. (2006). Exclusion of girls from education in rural Pakistan. Event Asia Newsletter, (2), 24.

27. Qaisar, S., Butt, I. H., \& Shiraz, M. (2020). Out of School Children in Rural Areas of Punjab: An Exploratory Study. sjesr, 3(1), 125-132. https://doi.org/10.36902/sjesr-vol3-iss1-2020(125-132)

28. Rao, V., \& Gupta, P. V. (2006). Low Female Literacy: Factors and Strategies. Australian Journal of Adult Learning, 46(1), 84-95. Retrieved from http://hdl.handle.net/2105/7023

29. Shah, S., \& Shah, U. (2012). Girl education in rural Pakistan. Revista Internacional de Sociología de la Educación, 1(2), 180-207.

30. Westbrook, J., Pryor, J., Orr, D., \& Durrani, N. (2013). Pedagogy, curriculum, teaching practices and teacher education in developing countries. Technical Report. https://www.gov.uk/government/publications/p edagogycurriculum-teaching-practices-and-teacher-education-in-developing-countries 